\section{Defining reference values for TSH: nearing perfection in a imperfect world}

\author{
Definição de valores de referência para TSH: \\ chegando à perfeição num mundo imperfeito
}

José Gilberto Henriques Vieira'

$\mathrm{T}$ he use of diagnostic laboratory tests usually includes a comparison of the result obtained in a given patient to a reference range. The definition of this reference or "normal" range is a priori simple: one has to measure the analyte in a "normal" population using a reference method, and there you are! Unfortunately life is not that easy. Routine methods frequently provide results that are not exactly comparable to the reference methods and, worst of nightmares, we don't really know what a "normal" population is.

Let's take the example of TSH measurement. Thyroid Stimulating Hormone (TSH) is a complex glycoprotein that contains two different subunits (alpha and beta) that organize as a heterodimeric complex. Being a glycosylated protein, the amount of sugar can vary substantially with implications on the antibody recognition as well as on the biological action. As a consequence, several forms are found in circulation. The seminal work of Utiger ( 1 ) describing the first practical TSH radioimmunoassay, introduced the possibility of routine measurement of TSH and its use as a diagnostic tool for the diagnosis of thyroid diseases. Since that time (1965) measuring TSH has become an extremely useful tool in the study of thyroid diseases. The first radioimmunoassay methods for the measurement of TSH had limitations in sensitivity, and at that time TRH stimulation tests were used to define hyperthyroidism and borderline cases of hypothyroidism (2). With methodological evolution provided by the availability of monoclonal antibodies and the introduction of the non-competitive immunometric design, sensitivity no longer poses a problem (3). Automatic, extremely sensitive and reproducible methods are provided by all the major diagnostic companies, and are widely available for clinical use. Assay specificity and comparability is a pending issue, but efforts in standardization and harmonization of the most used assays are strongly being pursued (4).

Thyroid diseases are quite common and sometimes oligo or asymptomatic. As a consequence TSH measurement became one of the most requested laboratory tests. The fact that the TSH results do not follow a Gaussian distribution poses an extra challenge, mainly in the definition of the upper limit of the normal range. Additionally, TSH levels in the normal population present a higher inter than intra individual variation, in other words, one should interpret a given TSH value bearing in mind that each person has his own range of variation of thyroid hormone levels, a phenomenon very well described by the Danish group of Andersen and cols. (5). Genetic reasons may be behind this characteristic (6).
${ }^{1}$ Associate professor, Division of Endocrinology, Escola Paulista de Medicina, Universidade Federal de São Paulo (Unifesp/ EPM); medical advisor, Grupo Fleury, São Paulo, SP, Brazil

Correspondência para: José Gilberto Henriques Vieira Av. General Valdomiro de Lima, 508

04344-903 - São Paulo, SP, Brazil jose.vieira@fleury.com.br 
In an effort to define a reliable normal range for TSH, the National Academy of Clinical Biochemistry (NACB, Washington, DC, USA) proposed very complex selection criteria, including absence of family history, negativity for thyroid antibodies and no visible or palpable goiter (7). The inclusion of a normal ultrasonographic examination of the cervical region was later proposed by a German group and the result was that from a blood donor population (adult and otherwise healthy), only $52 \%$ were considered for the definition of normal range of TSH (8).

In this ABE\&M issue, Rosario and cols. (9) publish a carefully designed paper defining the TSH normal values found in an adult Brazilian population. They used the same NACB criteria, without cervical ultrasonographic examination. From an initial population of 1,611 volunteers, $40 \%$ were excluded for not fulfilling the inclusion criteria, and the TSH assay used in the study is one of the most employed in our country. In the final adult population studied $(\mathrm{n}=960)$ the $2.5^{\text {th }}$ and the $97.5^{\text {th }}$ percentiles were 0.43 and $3.24 \mathrm{mUI} / \mathrm{L}$, respectively. The stringency of the selection criteria can be evaluated by the observation that the minimum and maximum values were 0.35 and $4.8 \mathrm{mUI} / \mathrm{L}$, respectively. These values are in concordance with most of the similar studies performed in different populations (8).

To have solid information about reference ranges is, by any perspective, extremely important. The availability of robust, sensitive and harmonized methods, as is the case nowadays for TSH, should prompt a more confident use of the assay results. However, one word of caution should be introduced with this new condition: to classify a patient as outside a normal range can have important implications. The diagnosis and treatment of subclinical thyroid dysfunction, in special patients with slightly high TSH levels, is a still debatable issue (10). To have better laboratory methods, and to define strict normal ranges, amplifies our diagnostic armamentarium as well as our responsibility of properly using the information.

\section{REFERENCES}

1. Utiger RD. Radioimmunoassay of human plasma thyrotropin. JCl. 1965; 44:1277-86.

2. Maciel RMB, Vieira JGH, Russo EMK, Kater CE, Juliano-Neto L, Chacra AR. Secreção de tirotrofina (TSH), triiodotironina (T3) e prolactina após a administração de hormônio liberador de tirotrofina (TRH) obtido por síntese em fase sólida. Rev Ass Med Brasil. 1979;25:135-40.

3. Vieira JGH, Kunii IS, Nishida SK, Matsumura LK, Russo EMK, Maciel RMB. Desenvolvimento e aplicação de um método imunofluorométrico para a dosagem de tirotrofina humana (TSH) no soro e em sangue total colhido em papel de filtro. Arq Bras Endocrinol Metab. 1992;36:7-12.

4. Thienpont LM, Van Uytfanghe K, Beastall G, Faix JD, leiri T, Miller WG, et al. Report of the IFCC Working Group for Standardization of Thyroid Function Tests; part 1: thyroid-stimulating hormone. Clin Chem. 2010; 56:902-11.

5. Andersen S, Pedersen KM, Bruun NH, Laurberg P. Narrow individual variations in serum T4 and T3 in normal subjects: a clue to the understanding of subclinical thyroid disease. J Clin Endocrinol Metab. 2002;87:1068-72.

6. Peters RP, vanToor H, KlootwijkW, de RijkeYB, Kuiper GGJM, Uitterlinden $A G$, et al. Polymorphisms in thyroid hormone pathway gene are associated with plasmaTSH and iodothyronine levels in healthy subjects. J Clin Endocrinol Metab. 2003;88:2880-8.

7. Baloch Z, Carayon P, Conte-Devolx B, Demers LM, Felt-Rasmussen U, Henry J-F, et al. Laboratory Medicine Guidelines. Laboratory support for the diagnosis and monitoring of thyroid disease. Thyroid. 2003;13:3-126.

8. Kratzsch J, Fiedler GM, Leichtle A, Brügel M, Buchbinder $S$, Otto $L$, et al. New reference intervals for thyrotropin and thyroid hormones based on National Academy of Clinical Biochemistry criteria and regular ultrasonography of the thyroid. Clin Chem. 2005;51:1480-6.

9. Rosario PW, Xavier ACM, Calsolari MR. TSH reference values for adult Brazilian population. Arq Bras Endocrinol Metab. 2010;54:603-6.

10. Biondi B, Cooper DS. The clinical significance of subclinical thyroid dysfunction. Endocrine Reviews 2008;29:76-131. 